\title{
Micropropagation of Baccharis antioquensis (Asteraceae) and photoinduction of polyphenols by $\mathrm{UV}$ radiation
}

\author{
Esther J. Naranjo-Gómez ${ }^{1}$, Miguel A. Puertas-Mejía ${ }^{2 *}$ Juan C. Mejía-Giraldo², \\ Anggy Z. Amaya-Nieto ${ }^{1}$ \& Lucia Atehortúa ${ }^{1}$ \\ 1. Biotechnology Group, Institute of Biology, University of Antioquia, Calle 70 No. 52-21, A.A. 1226, Medellin, \\ Colombia; esther.naranjo@udea.edu.co, azanzuly@gmail.com, latehor@gmail.com \\ 2. Research Group on Functional Compounds, Institute of Chemistry, University of Antioquia, Calle 70 No. 52-21, A.A. \\ 1226, Medellin, Colombia; miguel.puertas@udea.edu.co, jcamilomejiag@outlook.com \\ * Correspondence
}

Received 30-X-2017. Corrected 16-I-2018. Accepted 14-II-2018.

\begin{abstract}
Polyphenols are a large diversity of chemical types and interactions that can be responsible for a multiplicity of protective functions ranging from toxicity and light/UV shielding to signal transduction. Bacharis antioquensis has been described as a potential source of new photoprotective compounds with antioxidant capacity associated to polyphenols compounds. The aim of the present work was to develop a micropropagation protocol of $B$. antioquensis and evaluate the production of polyphenols by in vitro plants exposure to UVB radiation. Branches in juvenile stage of $B$. antioquensis were collected, desinfected and cultured on half strength Murashige and Skoog medium, supplemented or not with growth regulators (TDZ, BA or $\mathrm{GA}_{3}$ ) on light/darkness conditions and liquid/solid media. After UV treatments, the absorption coefficient in the UVA-UVB range, the antioxidant capacity and the total phenol content (TPC) from all tissue cultures and the wild tissue were evaluated. Growth regulators, light conditions and type of culture medium (solid or liquid) had a favorable effect on the response of explants. Treatments containing $\mathrm{BA}+\mathrm{GA}_{3}$ regulators ( 2 and $0.5 \mathrm{mg} / \mathrm{L}$ respectively) and TDZ $(0.5 \mathrm{mg} / \mathrm{L})$ showed positive results in bud growth in liquid medium and darkness. Results showed that UVR exhibited promoting effects on the accumulation of polyphenols, enhancing the absorption coefficient in the UVA-UVB range, the antiradical capacity and the TPC of B. antioquensis in vitro plants. Rev. Biol. Trop. 66(2): 754-764. Epub 2018 June 01.
\end{abstract}

Key words: $B$. antioquensis; elicitation; growth regulators; UVR; in vitro plants.

Plants synthesize a diversity of low molecular weight, structurally complex chemical compounds, commonly known as secondary metabolites (Moore, Andrew, Külheim, \& Foley, 2014) These are present mainly under stress conditions, but their absence does not cause harmful effects to the plants (Edreva, 2005; Edreva et al., 2008; Khan, Aliabbas, Kumar, \& Rajkumar, 2009). Among them phenolic compounds are one of the most pronounced secondary metabolites found in plants, play an important role in plant interactions as defense chemicals and their distribution is shown throughout the entire metabolic process
(Kurmukov, 2013). These can act as antioxidants, structural polymers (lignin), attractants for pollinators insects (flavonoids and carotenoids), UV screens (flavonoids), signal compounds (salicylic acid and flavonoids) and defense response chemicals (tannins and phytoalexins) (Brglez Mojzer, Knez Hrnčič, Škerget, Knez, \& Bren, 2016). From a human physiological standpoint, phenolic compounds are vital in defense responses such as antiaging, anti-inflammatory, antioxidant and antiproliferative activities (Irchhaiya et al., 2015; Khan et al., 2011; Lin et al., 2016). 
In the search for alternatives to produce desirable medicinal compounds from plants, biotechnological approaches, specifically plant tissue cultures, have the potential to act as supplemental alternatives to traditional agriculture in the industrial production of bioactive plant metabolites. Therefore, some advantages of in vitro culture plant systems over the conventional cultivation of whole plants are: useful compounds can be produced under controlled conditions independent of climatic changes or soil conditions; the cells of any plants, tropical or alpine, could easily be multiplied to yield their specific metabolites; automated control of cell growth and regulation of metabolite processes would reduce labor costs and improve productivity among other advantage (Bourgaud, Gravot, Milesi, \& Gontier, 2001; Giri \& Zaheer, 2016). Moreover, the evaluation of many secondary plant metabolites for bioprospecting should be a priority towards sustainable conservation and rational utilization of biodiversity in order to be applied in health, cosmetic and pharmaceutical industry.

Radiation induces damage to living cells mediated by the generation of free radicals and related reactive oxygen species (ROS) that damage cellular targets such as DNA, membrane lipids and proteins. Naturally occurring antioxidants are effective photoprotectors due to their ability to scavenge free radicals or neutralize their reactions (Londhe, Devasagayam, Foo, \& Ghaskadbi, 2009). Some species of Baccharis, belonging to the Asteraceae family of the tropical and subtropical areas of America and, particularly, Colombia, (Cuatrecasas, 1967, 1981; Díaz-Piedraita \& Cuatrecasas, 1991) have shown anti-inflammatory, antioxidant, antimicrobial and antifungal activities (Abad et al., 2006; Gené et al., 1996). Baccharis antioquensis has been described as a potential source of new photoprotective compounds with antioxidant capacities (MejíaGiraldo, Henao-Zuluaga, Gallardo, Atehortúa, \& Puertas-Mejía, 2016a; Mejía-Giraldo, Winkler, Gallardo, Sánchez-Zapata, \& PuertasMejía, 2016b). The advantages of polyphenols are their high accessibility, specificity of their response and low toxicity; whereas the main problems of these compounds are their rapid metabolism and low bioavailability. Recent studies have proposed the nanoformulation of polyphenols in order to prevent their rapid degradation and, consequently, enable delivery of increased concentrations to the target cells (Moga et al., 2016).

Conversely, biotic and abiotic elicitors, which are classified on their origin, have been considered as an effective way to stimulate secondary metabolites due to the fact that both plant defense mechanism and metabolite production are interrelated via secondary metabolism (Manaf, Rabie, \& Abd El-Aal, 2016). Among them, Ultraviolet-B radiation is an important abiotic factor that improves the production of secondary metabolites (Cetin, 2014) and low UVB doses increase the production of secondary metabolites (Gil, Pontin, Berli, Bottini, \& Piccoli, 2012). Therefore, the aim of the present work was to develop a micropropagation protocol of $B$. antioquensis and evaluate the production of polyphenols by tissue culture after UV-B treatment.

\section{MATERIALS AND METHODS}

Plant material: Branches in juvenile stage of $B$. antioquensis, were collected from wild individuals in July 2014, in Llanos de Cuivá, Yarumal, Antioquia, Colombia, at an altitude of 2730 m.a.s.l. (6 $6^{\circ} 49^{\prime} 50.6^{\prime \prime} \mathrm{N}-75^{\circ} 29^{\prime} 29.9^{\prime \prime}$ W). A voucher specimen was deposited in the Herbarium of the University of Antioquia, Colombia (HUA 194796).

Sterilization of plant material: Segments of 2-3 internodes and apical sprouts of $2 \mathrm{~cm}$ in length were washed with disinfectant soap Quirucidal and rinsed with running water. Subsequently, in laminar flow chamber, segments were immersed in Benomil fungicidal solution $(2 \mathrm{~g} / \mathrm{L})$ and antibiotic Streptomycin $(1 \mathrm{~g} / \mathrm{L})$ for 3 hours. Then were immersed in solution of sodium hypochlorite $(\mathrm{NaClO} 0.5$, 1 or $2 \%(\mathrm{v} / \mathrm{v}))$ or mercuric chloride $\left(\mathrm{HgCl}_{2}\right.$ $0.1 \%(\mathrm{w} / \mathrm{v}))$, for 15 minutes, for a total of 
three (3) treatments. Finally, explants of each treatment were washed 3 times with sterile distilled water.

\section{Development of micropropagation pro-} tocols: Explants were cultured on half strength Murashige and Skoog (1/2 MS) medium (Veraplakorn, 2016), supplemented with citric acid (AC) 200 ppm, ascorbic acid (AA) 200 ppm, polyvinylpyrrolidone (PVP) $500 \mathrm{ppm}$ and sucrose $2 \%(\mathrm{w} / \mathrm{v})$. All culture media were prepared with distilled water and homogenized with constant stirring. The initial $\mathrm{pH}$ was adjusted to 5.75 with $\mathrm{NaOH} 1 \mathrm{~N}$ and/or $\mathrm{HCl}$ $1 \mathrm{~N}$, before autoclaving and sterilized for 20 minutes at $121^{\circ} \mathrm{C}$ and 15 psi. Treatment with growth regulators 6- benzylaminopurine (BA), gibberellic acid $\left(\mathrm{GA}_{3}\right)$, thidiazuron (TDZ) were evaluated both in liquid and solid media, as well as two different lighting conditions (light/darkness), for a total of 16 treatments, including control (Murashige and Skoog basal medium without growth regulators; treatments 13-16), at $23 \pm 1{ }^{\circ} \mathrm{C}$ (Table 1). Treatments in liquid medium were kept in continuous agitation at $100 \mathrm{rpm}$ and the light intensity was $20 \mu \mathrm{mol} / \mathrm{m}^{2} \mathrm{~s}$. After which periodic subcultures were performed every 10 days during two months and then every 20 days.

\section{Elicitation of in vitro plants by UVR:} Groups of in vitro plants were exposed to different UVR treatments, (UV light produced by Philips UVC light, 200 - $280 \mathrm{~nm}$ ), evaluating different times and distances of exposure to this radiation, as well as two post treatment collection times (Table 2). The leaves of the plants were collected and the absorption coefficient in the UVA-UVB range, the antiradical capacity and the total phenol content (TPC) in all in vitro plants and the wild plant extracts were evaluated.

Extraction procedure: The extraction was performed according to the method described previously (Mejía-Giraldo et al., 2016b) with some modifications. Fresh vegetal material (leaves) was dried at room temperature protected from light. Then, dry vegetal material (DVM) was crushed using an electric

\section{TABLE 1}

Concentration of growth regulators used in each treatment to assess the establishment phase and in vitro multiplication of apexes and node of $B$. antioquensis

\begin{tabular}{|c|c|c|c|c|c|c|c|}
\hline \multirow{2}{*}{ Treatment } & \multicolumn{3}{|c|}{ Growth regulators $(\mathrm{mg} / \mathrm{L})$} & \multicolumn{2}{|c|}{ Media type } & \multicolumn{2}{|c|}{ Light conditions } \\
\hline & $\mathrm{BA}$ & $\mathrm{GA}_{3}$ & TDZ & Solid & Liquid & Light & Darkness \\
\hline 1 & 1 & 0.5 & - & $\mathrm{X}$ & & $\mathrm{X}$ & \\
\hline 2 & 1 & 0.5 & - & $\mathrm{X}$ & & & $\mathrm{X}$ \\
\hline 3 & 1 & 0.5 & - & & $\mathrm{X}$ & $\mathrm{X}$ & \\
\hline 4 & 1 & 0.5 & - & & $\mathrm{X}$ & & $\mathrm{X}$ \\
\hline 5 & 2 & 0.5 & - & $\mathrm{X}$ & & $\mathrm{X}$ & \\
\hline 6 & 2 & 0.5 & - & $\mathrm{X}$ & & & $\mathrm{X}$ \\
\hline 7 & 2 & 0.5 & - & & $X$ & $X$ & \\
\hline 8 & 2 & 0.5 & - & & $\mathrm{X}$ & & $\mathrm{X}$ \\
\hline 9 & - & - & 0.5 & $\mathrm{X}$ & & $\mathrm{X}$ & \\
\hline 10 & - & - & 0.5 & $\mathrm{X}$ & & & $\mathrm{X}$ \\
\hline 11 & - & - & 0.5 & & $\mathrm{X}$ & $X$ & \\
\hline 12 & - & - & 0.5 & & $\mathrm{X}$ & & $\mathrm{X}$ \\
\hline 13 control & - & - & - & $\mathrm{X}$ & & $\mathrm{X}$ & \\
\hline 14 control & - & - & - & $\mathrm{X}$ & & & $X$ \\
\hline 15 control & - & - & - & & $\mathrm{X}$ & $\mathrm{X}$ & \\
\hline 16 control & - & - & - & & $\mathrm{X}$ & & $\mathrm{X}$ \\
\hline
\end{tabular}

BA: 6- benzylaminopurine, $\mathrm{GA}_{3}$ : gibberellic acid, TDZ: thidiazuron. 
TABLE 2

UVR in vitro elicitation of $B$. antioquensis plants

\begin{tabular}{ccccc} 
Treatment & Light intensity $\left(\mathrm{mW} / \mathrm{m}^{2}\right)$ & Exposure distance $(\mathrm{cm})$ & Exposure time (min) & Collection time (hour) \\
T1 & $28-29$ & 49 & 5 & 24 \\
T2 & & & & 48 \\
T3 & & & 10 & 24 \\
T4 & $32-33$ & 39 & 5 & 48 \\
T5 & & & & 24 \\
T6 & & & 10 & 48 \\
T7 & - & - & & 24 \\
T8 & & & - & 48 \\
Control & & & & 0 \\
\hline
\end{tabular}

grinder (IKA, A11 basic S1). Briefly, $100 \mathrm{mg}$ of DVM crushed was subjected to extraction with $10 \mathrm{~mL}$ of methanol at room temperature (c.a. $25^{\circ} \mathrm{C}$ ) with magnetic stirring for 24 hours, and then extract was filtered. Finally, the crude extracts obtained were concentrated to dryness in a rotary evaporator (IKA, RV10 basic) at $40 \pm 2{ }^{\circ} \mathrm{C}$. The extraction yield (percentage of dry extract), TPC, antiradical capacity (DPPH assay) and absorptive capacity in UVA-UVB range, were evaluated in eight treatments of the elicitation procedure, in vitro plants control, and wild plant.

Antiradical capacity - DPPH Assay: For each extract, different concentrations were estimated according to the method described previously (Mejía-Giraldo, Gallardo, \& Puertas-Mejía, 2015) with some modifications, and the effective relative concentration $\left(\mathrm{EC}_{50}\right)$ at which $50 \%$ of DPPH has been removed was expressed as mg of dry extract/mmole DPPH radical, based on equation: Efficient Concentration $\left(\mathrm{EC}_{50}\right)=$ concentration of test at steady state/concentration of $\mathrm{DPPH}_{\mathrm{t}=0}$. The initial concentration of DPPH $(100 \mu \mathrm{mol} / \mathrm{L})$ in the reaction system was calculated according to a calibration curve $(\mathrm{y}=1.146 \mathrm{E}-2 \mathrm{x}-4.192 \mathrm{E}-3 ; \mathrm{r}=$ $0.9999)$ at $514 \mathrm{~nm}$, where $y=$ absorbance and $x=$ concentration of DPPH. All spectrophotometric data were obtained using a Thermo Scientific Evolution 60S UV-Visible Spectrophotometer. Disposable cuvettes (1 cm step length) were used for visible absorbance measurements for analyses. BHT (butylated hydroxy toluene) was used for comparison purposes.

Total phenol contents: TPC of samples were measured using a modified colorimetric Folin-Ciocalteu method (Puertas-Mejía, Rincón-Valencia, \& Mejía-Giraldo, 2015). Briefly, $10 \mu \mathrm{L}$ of extract solution and $615 \mu \mathrm{L}$ of deionized water were added to a test tube. Then, $125 \mu \mathrm{L}$ of Folin-Ciocalteu reagent was added to the solution and allowed to react for 5 minutes. After that, $1250 \mu \mathrm{L}$ of $20 \%$ sodium carbonate solution was added into the test tubes and mixed. The absorbance was read at 760 $\mathrm{nm}$ using an Evolution 60S Spectrophotometer (Thermo Fisher Scientific, Inc., Shanghai, China). The results are expressed as milligrams of galic acid equivalents per $g$ dry extract $(\mathrm{GAE} / \mathrm{g} \mathrm{DE})(\mathrm{y}=0.125627 \mathrm{X}+0.0312029$; $r=0.99864)$

UVA-UVB absorption coefficient: Briefly, an adequate dilution of the extracts was added in a quartz cuvette (1 cm step length) and their absorption spectrum (wavelengths $200-400 \mathrm{~nm}$ ) was recorded on a Thermo Scientific Evolution 60S UV-Visible Spectrophotometer, against a blank containing methanol. The absorption coefficient (absorbance/(mg dry extract $/ \mathrm{mL})$ ) was calculated at 290, 310, 340 and $380 \mathrm{~nm}$ (Mejía-Giraldo et al., 2015).

The results were expressed as the means \pm SD. All data were analyzed by one-way analysis of variance (ANOVA) followed by Tukey 
tests when appropriate, using $\mathrm{R}$ Development Core Team (2013). P values less than 0.05 ( $\mathrm{P}<$ 0.05 ) were considered significant (R Development Core Team, 2013).

\section{RESULTS}

Micropropagation: Disinfection protocols required a combined disinfection protocol of $\mathrm{NaClO} 0.5 \%(\mathrm{v} / \mathrm{v})$ and $\mathrm{HgCl}_{2} 0.1 \%$ (w/v), resulting in a disinfection rate greater than $70 \%$. Regarding to the establishment of explants, treatments containing $\mathrm{BA}+\mathrm{GA}_{3}$ regulators ( 2 and $0.5 \mathrm{mg} / \mathrm{L}$ respectively) and TDZ $(0.5 \mathrm{mg} / \mathrm{L})$ showed positive results. In addition to growth regulators, light conditions and type of culture medium (solid or liquid), had a favorable effect on the response of explants, since there was only bud growth with these growth regulators in liquid medium and dark
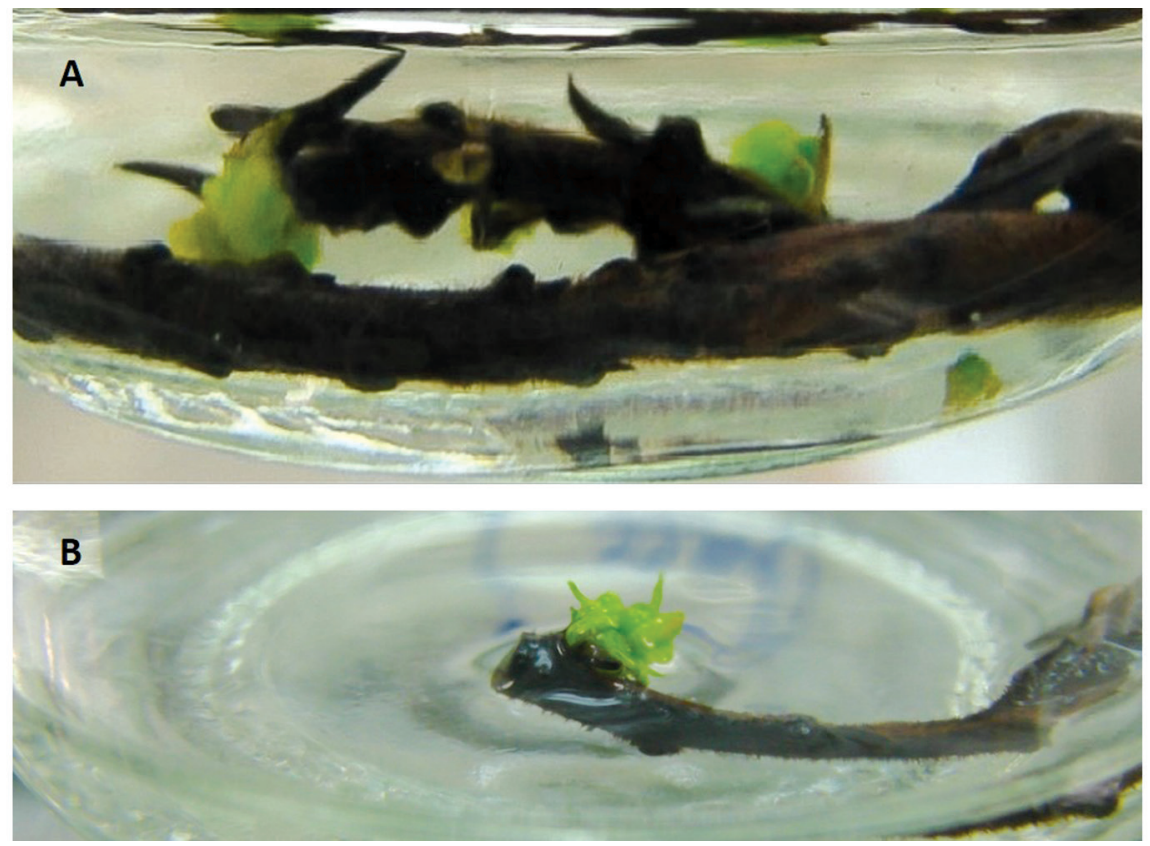

Fig. 1. A and B, tissue cultures with bud growth.

conditions. In summary, only treatments 8 and 12 (Table 1) were successful for development of buds in explants (Fig. 1).

After 25 days, explants were transferred to continuous light conditions to avoid the etiolation process, preserving state and composition of culture medium, and allowing their complete development. After 5 days, buds developed foliar primordia and de novo buds, each bud had between 3 and 4 buds which were individualized under the same conditions (Fig. 2). After 40 days of individualization, developed explants were transferred to culture medium

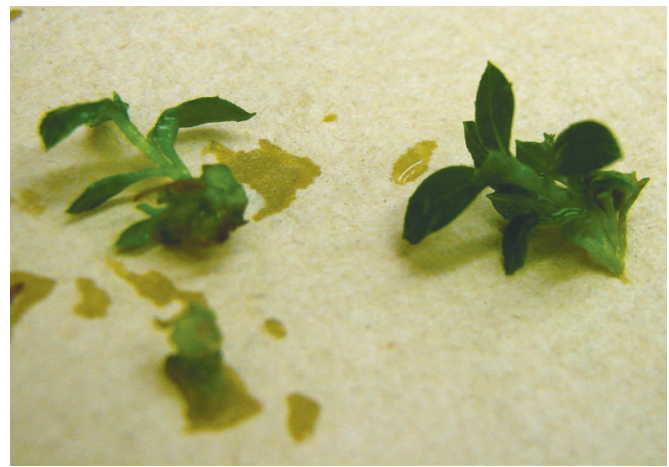

Fig. 2. Individualization of shoots. 
free of growth regulators, and observed for 60 days until complete plant development. The material obtained was used for multiplication from internodes, obtaining a multiplication coefficient of 4 in vitro plant/explant/ month (Fig. 3).

Elicitation: Exposure time and distances increase the absorption coefficient in the UVAUVB range and the antioxidant capacity. On the other hand, absorption capacity in UVA-UVB, TPC and antiradical capacity of extracts from wild plant of $B$. antioquensis exhibited higher values than extracts in each treatment of in vitro plants exposed to different conditions of UVB irradiation (Fig. 4, Table 2 and Table 3).

\section{DISCUSSION}

Because phenolization reactions were observed in tissue plant, antioxidant compounds such as ascorbic acid (AA), citric acid (CA) and PVP were added to the culture in order to stop the reaction. PVP addition help to phenolization control, which may be associated with its polymeric characteristics, that confer specific adsorptive functions for certain organic compounds such as phenols, preventing the oxidation and polymerization (Concepción et al., 2005). Similar reactions were reported in the culture of $B$. tridentate, but using a mixture of $\mathrm{CA}+\mathrm{AA}$ as antioxidant to stop the phenolization process (Kajiki \& Shepherd, 2006). Nevertheless, a combination of CA+AA+PVP was necessary to stop such reaction in the $B$. antioquensis culture, similar to $M$. esculenta reports (Bhatt \& Dhar, 2004). The best response to in vitro establishment of $B$. antioquensis was obtained from apexes, using $\mathrm{GA}_{3}+\mathrm{BAP}$ and TDZ as supplemental agent. However, during the multiplication stage these growing regulators promoted an accelerated production of sprouts without differences between them. Therefore, the multiplication process was carried out in a medium free of growth regulators, obtaining the development of complete plants (Fig. 3 and Fig. 4). These results were similar to those reported previously (Kajiki \&
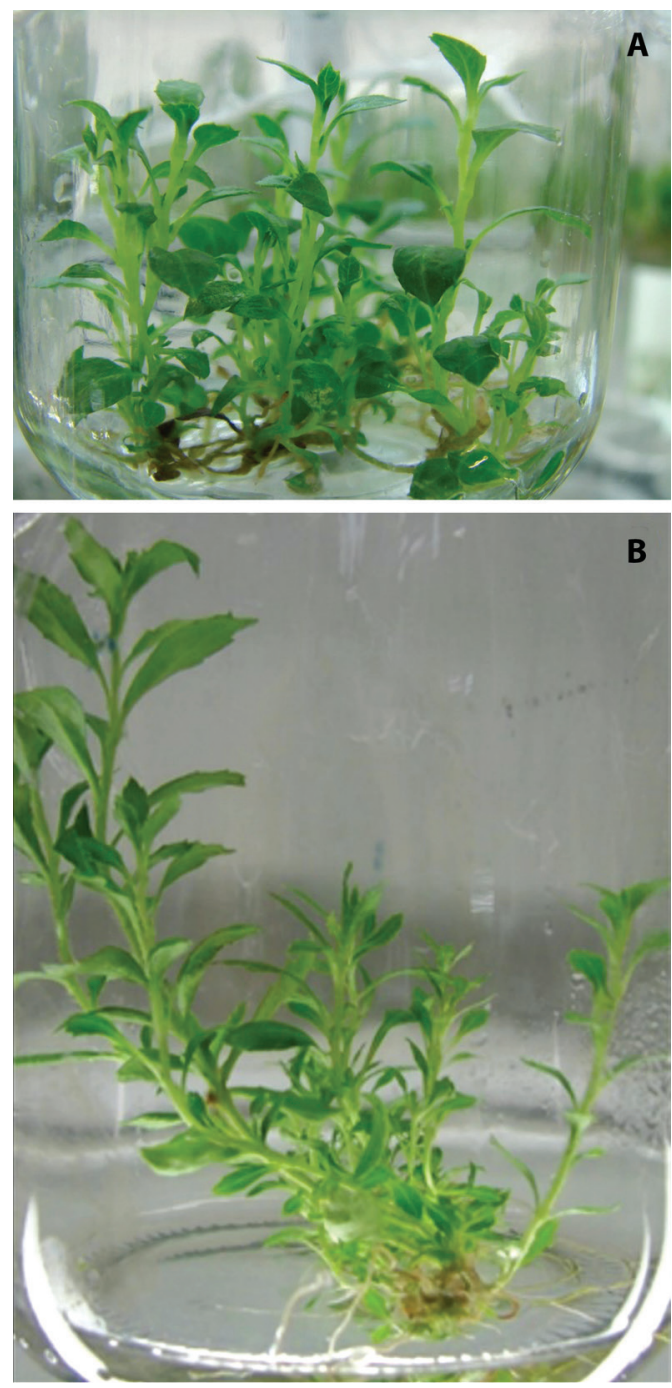

Fig. 3. A. in vitro plants with fully developed stem, leaf and radicular system. B. in vitro plants multiplied.

Shepherd, 2006) for B. tridentata, whose also reported that the apices were the explants with the best response in the establishment process, in addition to the cultivation of apices allow the maintenance of the identity of the genotype, which stimulate the process of multiplication of the species.

Previous studies have described that UV light radiation induced gene transcription process of enzymes involved in biosynthesis of secondary metabolites (Logemann, Tavernaro, 
TABLE 3

Extraction yield and antioxidant capacity of $B$. antioquensis in vitro plants

\begin{tabular}{cccc} 
Sample & \% Yield $\left(\% \mathrm{DE}^{*}\right)$ & $\mathrm{TPC}^{\ddagger}(\mathrm{mg}$ EAG/g MVS $)$ & Antiradical capacity EC $_{50}^{\dagger}$ \\
Wild plant & $27.65 \pm 1.28$ & $76.74 \pm 5.61$ & $0.13 \pm 0.01$ \\
Control & $38.74 \pm 0.80 \mathrm{a}$ & $8.64 \pm 0.31$ & $1.78 \pm 0.07$ \\
T1** & $35.92 \pm 0.55 \mathrm{~b}$ & $13.25 \pm 1.14 \mathrm{a}$ & $1.21 \pm 0.09 \mathrm{a}$ \\
T2 & $38.80 \pm 0.33 \mathrm{a}$ & $15.85 \pm 0.20 \mathrm{a}$ & $0.98 \pm 0.01 \mathrm{~b}$ \\
T3 & $41.19 \pm 1.43$ & $15.81 \pm 1.65 \mathrm{a}$ & $0.99 \pm 0.01 \mathrm{~b}$ \\
T4 & $37.27 \pm 0.12 \mathrm{a}, \mathrm{b}$ & $15.10 \pm 0.25 \mathrm{a}$ & $0.92 \pm 0.02 \mathrm{~b}$ \\
T5 & $36.64 \pm 0.38 \mathrm{~b}$ & $12.87 \pm 0.20 \mathrm{a}$ & $1.25 \pm 0.21 \mathrm{a}$ \\
T6 & $37.44 \pm 0.32 \mathrm{a}, \mathrm{b}$ & $15.48 \pm 0.21 \mathrm{a}$ & $0.98 \pm 0.01 \mathrm{~b}$ \\
T7 & $37.81 \pm 0.18 \mathrm{a}, \mathrm{b}$ & $12.52 \pm 0.30 \mathrm{a}$ & $1.25 \pm 0.06 \mathrm{a}$ \\
T8 & $38.75 \pm 1.13 \mathrm{a}$ & $15.18 \pm 0.50 \mathrm{a}$ & $1.16 \pm 0.02 \mathrm{a}$ \\
\hline
\end{tabular}

*See Table 2 for details. ** DE: Dry Extract. ${ }^{*}$ TPC: Total Phenol Content (mg gallic equivalents/g dry extract). ${ }^{\dagger}$ Effective Concentration at $50 \%(\mathrm{~g}$ dry extract $/ \mathrm{mmol} \mathrm{DPPH})$. Results are expressed as the mean value \pm standard deviation $(\mathrm{n}=3)$. Values in the same column followed by different letters are significantly different at the $5 \%$ level, according one-way analysis of variance (ANOVA) and Tukey tests.

Schulz, Somssich, \& Hahlbrock, 2000); in addition, excessive exposure to UVB radiation increases the synthesis of flavonoids (Agati, Galardi, Gravano, Romani, \& Tattini, 2002; Kotilainen, Tegelberg, Julkunen-Tiitto, Lindfors, \& Aphalo, 2008). Thus, the synthesis of polyphenols induced by UVR supposes that the characteristic photoprotection is related to the absorption of this solar radiation to increase the production of polyphenols (Agati et al., 2013; Agati \& Tattini, 2010; Harborne \& Williams, 2000). According to this premise, the in vitro plants showed important TPC values, scavenging capacity and absorption of UV radiation, but were lower than that observed on wild plants (Fig. 4, Table 3). These results are to be expected and reasonable because of the physiological aspect, principally the age of in vitro plants and environmental conditions when compared to wild plants.

Nevertheless, compare to control plant, the UVR showed a substantial effect on antioxidant and photoprotection properties in vitro plants. Phenolic composition of the foliar tissue samples changed significantly with irradiation $(\mathrm{P}<0.05)$. This result agrees with $\mathrm{Zu}$ reports (Zu et al., 2010) that found UVB radiation induced significant flavonoid accumulation that was able to protect the Taxus chinensis plant from radiation damage, although with some morphologic changes. Other researchers reported higher content of caffeic acid and its derivatives in callus culture and cell suspension of Echinacea purpurea after UVB irradiation (Manaf et al., 2016). Antognoni reported (Antognoni et al., 2007) that UVB irradiation of callus of $P$. incarnata was able to increase the production of all four glycosyl flavonoids and callus cultures treated with the UVB dose that enhanced flavonoid production showed a higher antioxidant activity compared to untreated callus. When Gil et al. (2012) exposed in vitro cultured plants of Vitis vinifera to two different UVB doses, the low UVB treatment increased the levels of the membrane-related triterpenes, being more notable in young leaves. Our results showed that the capacity of $B$. antioquensis in vitro plants to biosynthesize secondary metabolites can be enhanced by appropriate forms of elicitation with UVR. This effect has been reported in many others studies carried out in different species of plants such as Passiflora $s p$ (Antognoni et al, 2007), Rosmarinus officinalis (Luis, Pérez, \& González, 2007), Catharanthus roseus (Ramani \& Jayabaskaran, 2008), Hypericum perforatum (Germ, Stibilj, Kreft, Gaberščik, \& Kreft, 2010) and Ginkgo biloba (Sun et al., 2010). 

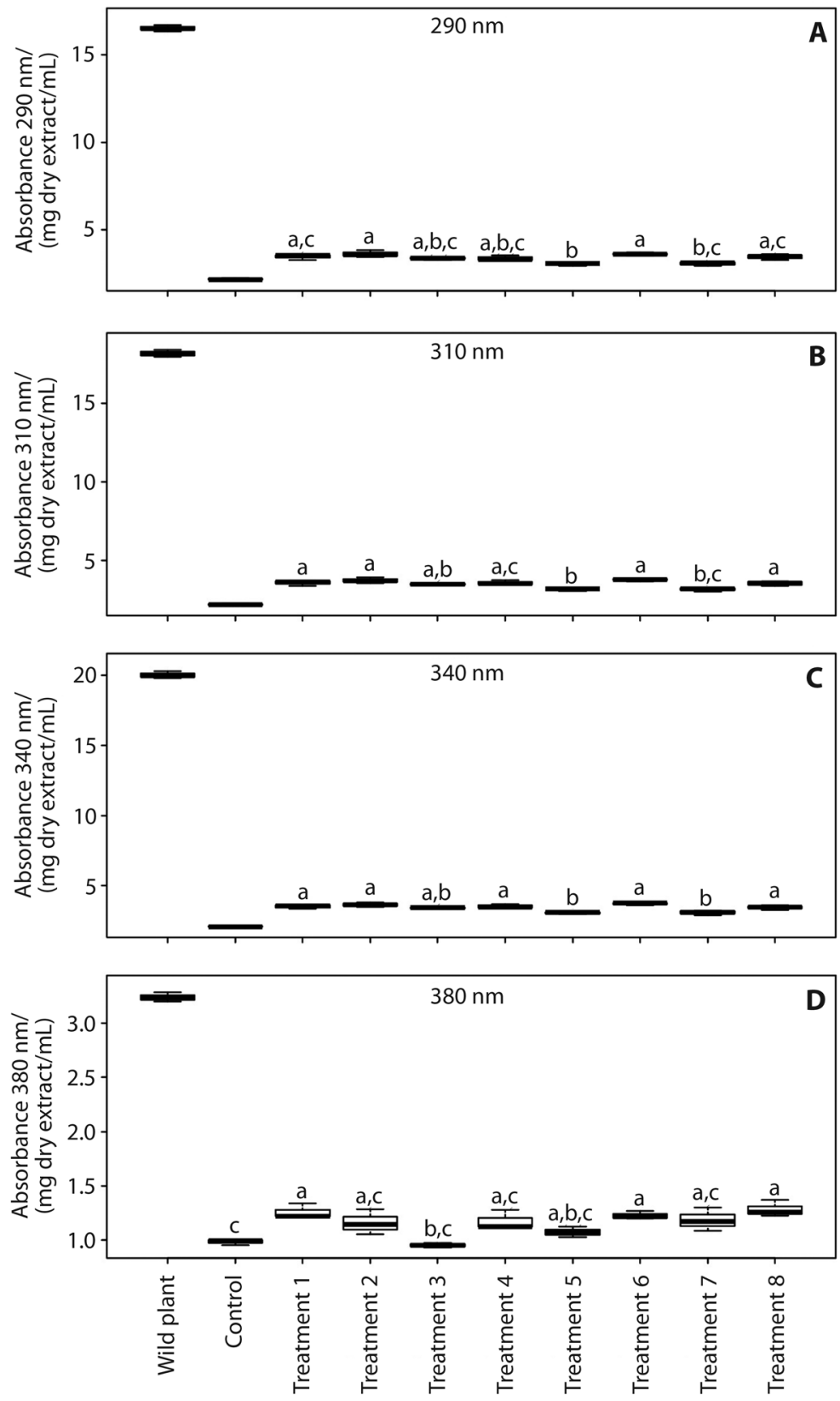

Fig. 4. UVA-UVB absorption coefficient assays of wild plant and in vitro plants extracts of $B$. antioquensis. The results are presented as the mean $\pm \mathrm{SD}(\mathrm{n}=3)$. The boxes with different letters have a statistically significant difference with a confidence level of $5 \%$, according one-way analysis of variance (ANOVA) and Tukey tests. Absorption coefficients at (a) $290 \mathrm{~nm}$, (b) $310 \mathrm{~nm}$, (c) $340 \mathrm{~nm}$, (d) $380 \mathrm{~nm}$. 
Finally, a protocol for in vitro introduction of $B$. antioquensis was first established using UVR, with a potential aspect related to future applications on genetic adaptations, elicitation and in vitro culture conditions in order to produce a large quantity of photoprotective compounds by sustainable and conservation practices of the species. The use of UVR as an eliciting agent of $B$. antioquensis was able to increase the content of polyphenolic compounds with UVA-UVB radiation absorption and antioxidant capacity, as compared to the control plant.

\section{ACKNOWLEDGMENTS}

This research was carried out with the financial support of CODI-University of Antioquia (Project no. IN632CE) and Colciencias (National Research Council) doctoral fellowship to JC Mejía-Giraldo. We also thank to the Institute of Biology- Laboratory of Plant Micropropagation facilities.

\section{RESUMEN}

Micropropagación de Baccharis antioquensis (Asteraceae) y fotoinducción de polifenoles mediante radiación UV. Los polifenoles son compuestos químicos con una diversidad de interacciones que pueden ser responsables de muchas funciones, que van desde la toxicidad hasta la protección y blindaje contra la luz/UV. Baccharis antioquensis es una fuente potencial de compuestos fotoprotectores con capacidad antioxidante. El objetivo del presente trabajo fue desarrollar un protocolo de micropropagación para $B$. antioquensis y evaluar la producción de polifenoles in vitro por exposición a la radiación UVB. Ramas juveniles fueron colectadas y cultivadas en medio de Murashige y Skoog (MS) y suplementadas o no con reguladores de crecimiento (TDZ, BA o $\mathrm{GA}_{3}$ ) en diferentes condiciones de luz/oscuridad y medios líquidos/sólidos. Después de los tratamientos UVR, se midió el espectro de absorción UV y se evaluó el coeficiente de absorción en la región UVA-UVB, la capacidad antioxidante y TPC tanto en las plantas in vitro como en las plantas silvestres. Los tratamientos que contenían reguladores $\mathrm{BA}+\mathrm{GA}_{3}(2$ y 0.5 $\mathrm{mg} / \mathrm{L}$ respectivamente) y $\mathrm{TDZ}(0.5 \mathrm{mg} / \mathrm{L})$ mostraron resultados positivos en el crecimiento del brote en medio líquido y en condiciones de oscuridad. Los resultados mostraron que la UVR tiene efectos promotores sobre la acumulación de metabolitos secundarios, aumentando el coeficiente de absorción en la región UVA-UVB, la capacidad antiradicalaria y TPC en las plantas in vitro.

Palabras clave: B. antioquensis; elicitación; protector solar natural; UVR; plantas in vitro.

\section{REFERENCES}

Abad, M. J., Bessa, A. L., Ballarin, B., Aragón, O., Gonzales, E., \& Bermejo, P. (2006). Anti-inflammatory activity of four Bolivian Baccharis species (Compositae). Journal of Ethnopharmacology, 103(3), 338-344. http://doi.org/10.1016/j.jep.2005.08.024

Agati, G., Brunetti, C., Di Ferdinando, M., Ferrini, F., Pollastri, S., \& Tattini, M. (2013). Functional roles of flavonoids in photoprotection: new evidence, lessons from the past. Plant Physiology and Biochemistry: PPB / Société Française de Physiologie Végétale, 72, 35-45. http://doi.org/10.1016/j.plaphy.2013.03.014

Agati, G., Galardi, C., Gravano, E., Romani, A., \& Tattini, M. (2002). Flavonoid Distribution in Tissues of Phillyrea latifolia L. Leaves as Estimated by Microspectrofluorometry and Multispectral Fluorescence Microimaging. Photochemistry and Photobiology, 76(3), 350-360. http://doi. org/10.1562/0031-8655(2002)0760350FDITOP2.0.CO2

Agati, G., \& Tattini, M. (2010). Multiple functional roles of flavonoids in photoprotection. New Phytologist, 186(4), 786-793. http://doi. org/10.1111/j.1469-8137.2010.03269.x

Antognoni, F., Zheng, S., Pagnucco, C., Baraldi, R., Poli, F., \& Biondi, S. (2007). Induction of flavonoid production by UV-B radiation in Passiflora quadrangularis callus cultures. Fitoterapia, 78(5), 345-352. http:// doi.org/https://doi.org/10.1016/j.fitote.2007.02.001

Bhatt, I. D., \& Dhar, U. (2004). Factors controlling micropropagation of Myrica esculenta buch. - Ham. ex D. Don: a high value wild edible of Kumaun Himalaya. African Journal of Biotechnology, 3(10), 534-540. http://doi.org/10.5897/AJB2004.000-2097

Bourgaud, F., Gravot, A., Milesi, S., \& Gontier, E. (2001). Production of plant secondary metabolites: a historical perspective. Plant Science, 161(5), 839-851. http://doi.org/https://doi.org/10.1016/ S0168-9452(01)00490-3

Brglez Mojzer, E., Knez Hrnčič, M., Škerget, M., Knez, Ž., \& Bren, U. (2016). Polyphenols: Extraction Methods, Antioxidative Action, Bioavailability and Anticarcinogenic Effects. Molecules. http://doi.org/10.3390/ molecules 21070901

Cetin, E. S. (2014). Induction of secondary metabolite production by UV-C radiation in Vitis vinifera L. Öküzgözü callus cultures. Biological Research, 47(1), 37. http://doi.org/10.1186/0717-6287-47-37 
Concepción, O., Nápoles, L., Pérez, A. T., Peralta, N., Hernández, M., \& Trujillo, R. (2005). Efecto de tres antioxidantes en el Cultivo in Vitro de ápices de guayaba (Psidium guajava). Relación entre el origen del explante y el contenido de compiuestos fenólicos. Red de Revistas Cinetificas de América Latina, El Caribe, España Y Portugal, 26(1), 33-39.

Cuatrecasas, J. (1967). Revision de las especies colombianas del genero Baccharis. Revista de La Academica Colombiana de Ciencias Exactas, Física Y Naturales, 13(49), 5-102.

Cuatrecasas, J. (1981). Studies in Neotropical Senecioneae. II. Transfers to genus Pentacalia of North Andean species. Phytologia., 49, 241-260. http://doi. org/10.5962/bhl.part.15138

Díaz-Piedraita, S., \& Cuatrecasas, J. (1991). Nueva especie de Baccharis (Asteraceae) de Colombia. Revista de La Academica Colombiana de Ciencias Exactas, Física Y Naturales, 18(69), 127-129.

Edreva, A. (2005). The importance of non-photosynthetic pigments and cinnamic acid derivatives in photoprotection. Agriculture, Ecosystems \& Environment, 106(2-3), 135-146. http://dx.doi.org/10.1016/j. agee.2004.10.002

Edreva, A., Velikova, V., Tsonev, T., Dagnon, S., Gürel, A., Aktaş, L., \& Gesheva, E. (2008). Stress-protective role of secondary metabolites: diversity of functions and mechanisms. General and Applied Plant Physiology, 34(1-2), 67-78. http://doi.org/10.1093/aob/ $\operatorname{men} 125$

Gené, R. M., Cartaña, C., Adzet, T., Marín, E., Parella, T., \& Cañigueral, S. (1996). Anti-inflammatory and analgesic activity of Baccharis trimera: identification of its active constituents. Planta Medica, 62(3), 232235. http://doi.org/10.1055/s-2006-957866

Germ, M., Stibilj, V., Kreft, S., Gaberščik, A., \& Kreft, I. (2010). Flavonoid, tannin and hypericin concentrations in the leaves of St. John's wort (Hypericum perforatum L.) are affected by UV-B radiation levels. Food Chemistry, 122(3), 471-474. https://doi. org/10.1016/j.foodchem.2010.03.008

Gil, M., Pontin, M., Berli, F., Bottini, R., \& Piccoli, P. (2012). Metabolism of terpenes in the response of grape (Vitis vinifera L.) leaf tissues to UV-B radiation. Phytochemistry, 77, 89-98. https://doi. org/10.1016/j.phytochem.2011.12.011

Giri, C. C., \& Zaheer, M. (2016). Chemical elicitors versus secondary metabolite production in vitro using plant cell, tissue and organ cultures: recent trends and a sky eye view appraisal. Plant Cell, Tissue and Organ Culture (PCTOC), 126(1), 1-18. http://doi.org/10.1007/ s11240-016-0985-6

Harborne, J. B., \& Williams, C. A. (2000). Advances in flavonoid research since 1992
Phytochemistry, 55(6), 481-504. http://dx.doi. org/10.1016/S0031-9422(00)00235-1

Irchhaiya, R., Kumar, A., Yadav, A., Gupta, N., Kumar, S., Gupta, N., ... Gurjar, H. (2015). Metabolites in Plants and Its Classification. World Journal of Pharmacy and Pharmaceutical Sciences, 4(1), 287-305.

Kajiki, F. O., \& Shepherd, S. L. K. (2006). Micropropagação Da Espécie Nativa Baccharis tridentata Vahl. (Asteraceae). Revista Brasileira de Plantas Medicinais, 8(2), 42-47.

Khan, K. Y., Khan, M. A., Niamat, R., Munir, M., Fazal, H., \& Mazari, P. (2011). Element content analysis of plants of genus Ficus using atomic absorption spectrometer. African Journal of Pharmacy and Pharmacology, 5(March), 317-321. http://doi.org/10.5897/ AJPP10.339

Khan, M. Y. M. Y., Aliabbas, S., Kumar, V., \& Rajkumar, S. (2009). Recent advances in medicinal plant biotechnology. Indian Journal of Biotechnology, 8(January), 9-22. Retrieved from isi:000264540700001

Kotilainen, T., Tegelberg, R., Julkunen-Tiitto, R., Lindfors, A., \& Aphalo, P. J. (2008). Metabolite specific effects of solar UV-A and UV-B on alder and birch leaf phenolics. Global Change Biology, 14(6), 1294-1304. http://doi.org/10.1111/j.1365-2486.2008.01569.x

Kurmukov, A. G. (2013). Phytochemistry of medicinal plants. Medicinal Plants of Central Asia: Uzbekistan and Kyrgyzstan, 1(6), 13-14. http://doi. org/10.1007/978-1-4614-3912-7_4

Lin, D., Xiao, M., Zhao, J., Li, Z., Xing, B., Li, X., ... Chen, S. (2016). An Overview of Plant Phenolic Compounds and Their Importance in Human Nutrition and Management of Type 2 Diabetes. Molecules, 21(10), 1374. http://doi.org/10.3390/molecules21101374

Logemann, E., Tavernaro, A., Schulz, W., Somssich, I. E., \& Hahlbrock, K. (2000). UV light selectively coinduces supply pathways from primary metabolism and flavonoid secondary product formation in parsley. Proceedings of the National Academy of Sciences , 97(4), 1903-1907. http://doi.org/10.1073/ pnas.97.4.1903

Londhe, J. S., Devasagayam, T. P., Foo, L. Y., \& Ghaskadbi, S. S. (2009). Radioprotective properties of polyphenols from Phyllanthus amarus Linn. J Radiat Res, 50(4), 303-309. http://doi.org/10.1269/jrr.08096

Luis, J. C., Pérez, R. M., \& González, F. V. (2007). UV-B radiation effects on foliar concentrations of rosmarinic and carnosic acids in rosemary plants. Food Chemistry, 101(3), 1211-1215. https://doi.org/10.1016/j. foodchem.2006.03.023

Manaf, H. H., Rabie, K. A. E., \& Abd El-Aal, M. S. (2016). Impact of UV-B radiation on some biochemical changes and growth parameters in Echinacea purpurea 
callus and suspension culture. Annals of Agricultural Sciences, 61(2), 207-216. http://dx.doi.org/10.1016/j. aoas.2016.08.001

Mejía-Giraldo, J., Gallardo, C. \& Puertas-Mejía, M. (2015). In vitro photoprotection and antioxidant capacity of Sphagnum meridense extracts, a novel source of natural sunscreen from the mountains of Colombia. Pure and Applied Chemistry, 87(9-10), pp. 961-970. http://doi.org/10.1515/pac-2015-0302

Mejía-Giraldo, J. C., Henao-Zuluaga, K., Gallardo, C., Atehortúa, L., \& Puertas-Mejía, M. A. (2016). Novel In Vitro Antioxidant and Photoprotection Capacity of Plants from High Altitude Ecosystems of Colombia. Photochemistry and Photobiology, 92(1), 150-157. http://doi.org/10.1111/php.12543

Mejía-Giraldo, J. C., Winkler, R., Gallardo, C., SánchezZapata, A. M., \& Puertas-Mejía, M. A. (2016). Photoprotective Potential of Baccharis antioquensis (Asteraceae) as Natural Sunscreen. Photochemistry and Photobiology, 92(5), 742-752. http://doi. org/10.1111/php.12619

Moga, A. M., Dimienescu, G. O., Arvatescu, A. C., Mironescu, A., Dracea, L., \& Ples, L. (2016). The Role of Natural Polyphenols in the Prevention and Treatment of Cervical Cancer-An Overview. Molecules, 21(8), 1055 . http://doi.org/10.3390/molecules21081055

Moore, B. D., Andrew, R. L., Külheim, C., \& Foley, W. J. (2014). Explaining intraspecific diversity in plant secondary metabolites in an ecological context. New Phytologist, 201(3), 733-750. http://doi.org/10.1111/ nph. 12526
Puertas-Mejía, M. A., Rincón-Valencia, S., \& Mejía-Giraldo, J. C. (2015). Screening of UVA/UVB absorption and in vitro antioxidant capacity of bejaria aestuans, cavendishia pubescens and cavendishia bracteata leaf extracts. Research Journal of Medicinal Plant, 9(8), 435-441. http://doi.org/10.3923/rjmp.2015.435.441

R Core Team (2013). R: A language and environment for statistical computing. R Foundation for Statistical Computing, Vienna, Austria. URL http://www.Rproject.org/

Ramani, S., \& Jayabaskaran, C. (2008). Enhanced catharanthine and vindoline production in suspension cultures of Catharanthus roseus by ultraviolet-B light. Journal of Molecular Signaling, 3, 9. http://doi. org/10.1186/1750-2187-3-9

Sun, M., Gu, X., Fu, H., Zhang, L., Chen, R., Cui, L., ... Tian, J. (2010). Change of secondary metabolites in leaves of Ginkgo biloba L. in response to UV-B induction. Innovative Food Science \& Emerging Technologies, 11(4), 672-676. https://doi. org/10.1016/j.ifset.2010.08.006

Veraplakorn, V. (2016). Micropropagation and callus induction of Lantana camara L. - A medicinal plant. Agriculture and Natural Resources, 50(5), 338-344. http://doi.org/10.1016/j.anres.2016.12.002

Zu, Y., Pang, H.-H., Yu, J.-H., Li, D.-W., Wei, X.-X., Gao, Y.-X., \& Tong, L. (2010). Responses in the morphology, physiology and biochemistry of Taxus chinensis var. mairei grown under supplementary UV-B radiation. Journal of Photochemistry and Photobiology B: Biology, 98(2), 152-158. http://dx.doi.org/10.1016/j. jphotobiol.2009.12.001 